\title{
THE EFFECT OF FINANCIAL AND NON FINANCIAL COMPENSATION ON EMPLOYEE JOB SATISFACTION OF PT BANK PERKREDITAN RAKYAT (BPR) MODERN EXPRESS OF AMBON BRANCH
}

\author{
Hasna Ohorella \\ Department of Business Administration, Sekolah Tinggi Ilmu Administrsi Trinitas Ambon, \\ Indonesia \\ E-mail: ohorellahasna@yahoo.com
}

\begin{abstract}
The increasing development of the business world in line with the improvement in economic conditions in Indonesia requires intense competition in it. The success of a company in achieving its goals does not only depend on the existing facilities and infrastructure but also depends on the performance of its employees. This research is an explanatory research or research that explains the causal relationship among variables through hypothesis testing about the effect of compensation on job satisfaction of employees of PT. Bank Perkreditan Rakyat (BPR) Modern Express Ambon. Based on the results of the hypothesis testing shows that financial compensation and non-financial compensation tested had positive and significant effect on job satisfaction of employees of PT. BPR Modern Express Ambon. This shows that the higher attention of leaders towards financial and non-financial compensation will affect the increase in employee job satisfaction.
\end{abstract}

\section{KEY WORDS}

Compensation, job, satisfaction, employees.

The success of a company in achieving its goals is not only depend on the existing facilities and infrastructure, but also depends on the performance of its employees. Every company will always try to improve the performance of its employees by meeting the needs of employees, paying attention to subordinates, and placing employees as part of company assets, not merely considering employees as workers. Such conditions can be realized through the job satisfaction approach.

Robbins (2001: 78) states that job satisfaction is a general attitude towards one's work that shows the difference between the number of awards received by workers and the number of jobs that workers believe they should receive. In this case what is meant by this attitude are things that related to work along with specific factors such as supervision, salary, incentives (bonuses) and benefits, opportunities to get promotions, working conditions, experience on the skills work, fair and non-detrimental work assessment, social relations in a good work environment, fast resolution of complaints, and good treatment from leaders towards employees.

According to Syafrizal (2011: 39), Jung et al. (2019), Sultan et al. (2019), Stamolampros et al. (2019), Zainudin et al. (2019), Froese (2019), job satisfaction on employees has a very important meaning for the company. Satisfied employees will certainly survive in the company and be able to work productively (Syaifullah et al., 2019; Honeyman, \& Jana, 2019). Job dissatisfaction has often been identified as the most important reason why individuals leave their jobs. In order to create job satisfaction for employees, companies can conduct by providing effective compensation. Compensation can be in the form of financial compensation or non-financial compensation (Schmitt \& Dörfel, 1999; Arampatzi et al., 2019). According to Simamora (2004: 10), financial compensation is compensation that consists of payments that someone gets in the form of salary / wages, bonuses and benefits. Meanwhile, non-financial compensation is compensation that can be in the form of all financial rewards that are not covered by direct financial compensation, including selfsatisfaction, psychological, and physical environment in which the person works. Thus, the 
compensation provided by the organization can be a means to retain employees who are truly competent.

The problem in this study is seen from how a leader in determining the amount of compensation policies in accordance with the needs and desires of employees, as well as organizations or companies so that no party feels disadvantaged. Another problem studied, namely related to how to create job satisfaction between employees and the organization or company so that could increase the productivity of the organization or company. The purpose of this research is to find out and analyze the effect of financial and non financial compensation on the job satisfaction of employees of PT. Bank Perkreditan Rakyat (BPR) Modern Express Ambon.

\section{METHODS OF RESEARCH}

This type of research is explanatory research or research that explains the causal relationship among variables through hypothesis testing. The sampling technique in this study using simple random techniques namely amounted to 45 people taken at PT. BPR Modern Express from Ambon Branch with the sample formula is:

Where:

$$
\mathrm{n}=\frac{\mathrm{N}}{1+N(d)^{2}}
$$

$\mathrm{n}=$ Number of Samples;

$\mathrm{N}=$ Total population;

$d=$ Constant (\% standard error rate that can be tolerated for each sample, in this case a $10 \%$ error rate is used).

$$
\mathrm{n}=\frac{81}{1+81(0,1)^{2}} \text { or } 45 \text { respondents }
$$

In this study a questionnaire was used to reveal both the independent and dependent variables. The analysis model used is Multiple Linear Regression to determine the independent variable on the dependent variable. The multiple linear regression equation can be formulated as follows:

$$
Y=a+\beta_{1} X_{1}+\beta_{2} X_{2}+e
$$

Where:

Y: Job satisfaction;

$\mathrm{X} 1$ : Financial compensation;

$\mathrm{X} 2$ : Non-financial compensation;

a: Intercept Coefficient (Constant);

$b_{1}, b_{2}$ : Coefficient of Regression direction;

e: Confounding (error) variable.

\section{RESULTS OF STUDY}

PT. BPR Modern Express was established on November $28^{\text {th }}, 1988$ based in Tulehu, Salahutu Subdistrict, Central Maluku Regency, based on deed No. 60 of Tuasikal Agua, SH Notary in Ambon and amended by deed No. 235 of the same on June $14^{\text {th }}, 1985$. This deed of establishment was approved by the Minister of Justice of the Republic of Indonesia with a Decree No. C2-5780.HT.01.01.TH 89 dated June 24 ${ }^{\text {th }}$, 1989. The Company's Articles of Association have been amended several times, most recently by deed No. 23 dated December $27^{\text {th }}, 2004$ from Umar Saili, SH notary in Ambon, regarding changes in the company's authorized capital. This amendment was approved by the Minister of Law and Human Rights of the Republic of Indonesia with Decree No.C-05130HT.01.04.TH 2005 
dated February $25^{\text {th }}$, 2005. The company is domiciled in Ambon with its head office on $\mathrm{Jl}$. Diponegoro No. 29.

Characteristics of respondents in this study were seen from the aspects of gender, age, and level of education by taking a sample of 45 respondents who were employees of PT. BPR Modern Express from Ambon Branch. The characteristics of respondents in this study can be observed in the following table 1.

Table 1 - Characteristics of Research Respondents in PT. BPR Modern Express of Ambon Branch

\begin{tabular}{|c|c|c|}
\hline Characteristics of Respondents & Frequency & Percentage (\%) \\
\hline $\begin{array}{cl}\text { Gender } & \\
\bullet & \text { Male } \\
\bullet & \text { Female }\end{array}$ & $\begin{array}{l}25 \\
20\end{array}$ & $\begin{array}{l}55,55 \% \\
44,44 \%\end{array}$ \\
\hline $\begin{aligned} & \text { Age } \\
&-21-30 \\
&- 31-40 \\
&- 41-50 \\
&-\quad>51 \\
&\end{aligned}$ & $\begin{array}{c}25 \\
11 \\
9 \\
-\end{array}$ & $\begin{array}{c}55,55 \% \\
24,44 \% \\
20 \% \\
-\end{array}$ \\
\hline $\begin{array}{cc}\text { Education Level } \\
\bullet \quad \text { S1 } \\
\bullet \quad \text { D3 } \\
\bullet \quad \text { S2 }\end{array}$ & $\begin{array}{c}26 \\
17 \\
2\end{array}$ & $\begin{array}{c}57,77 \% \\
37,78 \% \\
4,44 \%\end{array}$ \\
\hline $\begin{array}{cl}\text { Duration of Work } \\
\qquad \quad 1-5 \text { Years } \\
\text { - } & 5-10 \text { years } \\
\text { - } & \text { More than } 10 \text { years }\end{array}$ & $\begin{array}{c}33 \\
9 \\
3\end{array}$ & $\begin{array}{c}73,33 \% \\
20 \% \\
6,67 \%\end{array}$ \\
\hline
\end{tabular}

Source: Primary Data Processed.

Based on table 1 can be explained that the respondents characteristics of PT. BPR Modern Express of Ambon Branch based on gender is dominated by male gender indicated by 20 people or $44,4 \%$.

While the characteristics of respondents when viewed from the age classification obtained that the age of the employees of PT. BPR Modern Express of Ambon Branch on average the most are at the age of $21-30$ years old or equal to 25 people or $55,5 \%$ and the number of other respondents' age characteristics are at the age of 31-40 years old amounted to 11 people or $24,4 \%$ while the rest are at the age of $41-50$ years old as many as 9 people or $20 \%$.

For the classification of the characteristics of respondents according to the level of education most dominated by respondents whose education level is $\mathbf{S 1}$, as many as 26 people or $57,7 \%$.

For the classification of the length of work as many as 33 respondents or $73,33 \%$ have worked in the company for $1-5$ years. A total of 9 or $20 \%$ for $5-10$ years and employees who work for more than 10 years namely equal to 3 or $6,67 \%$. These results indicate that the length of work of most employees of PT. BPR Modern Express of Ambon Branch, namely for 1 - 5 years.

Based on the results of the regression analysis calculated using the SPSS for windows program, a summary of the results of the multiple linear regression analysis can be arranged as follows.

Table 2 - Recapitulation of Multiple Linear Regression Analysis

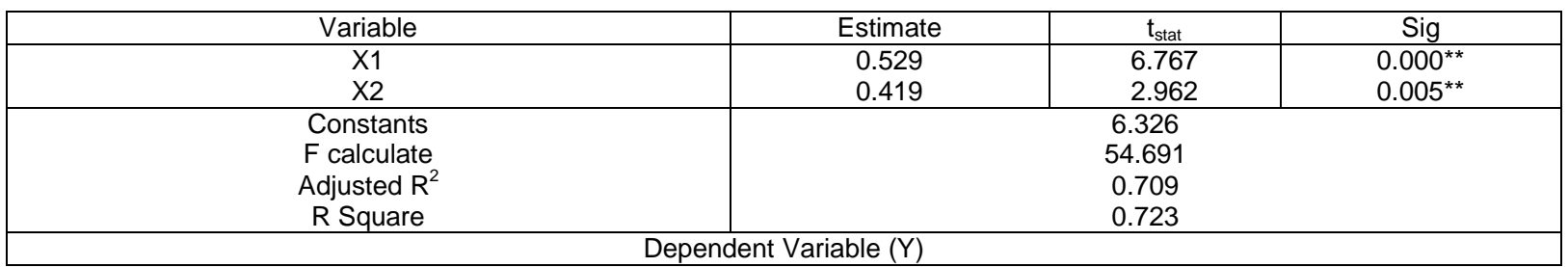

Source: Primary Data Processed, 2015. 
From the table above can be made multiple linear regression equations as follows.

$$
Y=6.326+0.529(\text { Komp. Finansial) }+0.419(\text { Komp. Non Finansial) }
$$

Constants (a) equal to 6.326 indicate the amount of job satisfaction of employees of PT. BPR Modern Express Ambon if there is no influence from financial compensation and non-financial compensation variables. In other words, this data shows the value of job satisfaction if the independent variable that affects the value is considered zero.

The regression coefficient of financial compensation $\left(X_{1}\right)$ shows the financial compensation variable has an influence of 0.529 on the job satisfaction of employees of PT. BPR Modern Express Ambon. The positive value of the regression coefficient shows unidirectional effect, meaning that the higher the financial compensation provided will lead to higher job satisfaction of employees of PT. BPR Modern Express Ambon. Or it can also be said that every increase (addition) 1 unit variable X1 (financial compensation) there will be a tendency to increase the job satisfaction variable by 0,529 assuming the other independent variables are constant.

The regression coefficient of non financial compensation $\left(X_{2}\right)$ shows non-financial compensation variable has an influence of 0.419 on the job satisfaction of employees of PT. BPR Modern Express Ambon. The positive value of the regression coefficient shows unidirectional effect, it means that the higher non-financial compensation in the organization will lead to higher job satisfaction of employees of PT. BPR Modern Express Ambon. It can also be said that each increase (addition) 1 unit variable X2 (non financial compensation) will increase the dependent variable of job satisfaction by 0.419 assuming the other independent variables are constant.

The magnitude of the coefficient of determination $\left(R^{2}\right)=0.723$ and after adjusted to become Adjusted $R$ square equal to 0.709 shows that financial compensation and nonfinancial compensation collectively contributed $70,9 \%$ on the changes in job satisfaction of employees of PT. BPR Modern Express Ambon while the remaining $29,1 \%$ is the contribution of other variables which not observed in this study.

To test the hypothesis about the existence of a positive and significant effect between the variable financial compensation (X1) and non-financial compensation variable (X2) on job satisfaction of employees of PT. BPR Modern Express Ambon used the F Test, by comparing the $\mathrm{F}$ calculate with the $\mathrm{F}$ table.

Confidence level of $95 \%(\alpha=0,05)$ and $d f=2: 42$ obtained the value of $F$ table of $=3$, 22 while the value of $F$ calculate $=54.691$. Thus the value of $F$ calculate $>F$ table so that $H_{0}$ is rejected or $\mathrm{H}_{\mathrm{a}}$ is accepted, so that it is statistically proven that there is a significant influence between the variables of financial compensation and non-financial compensation collectively on the job satisfaction of employees of PT. BPR Modern Express Ambon. Thus, hypothesis I which states that suspected the existence of positive and significant influence between financial compensation and non-financial compensation variables on job satisfaction of employees of PT. BPR Modern Express Ambon can be accepted and statistically tested.

Based on the results of the regression analysis obtained the value of $t$ calculate for financial compensation (X1) equal to 6.767 while at $\alpha=0.05$ and $\mathrm{df}=42$ obtained the value of $t$ table $=1.681$ because $t$ calculate $>t$ table. This data proves that partially financial compensation variables significantly has influence on employee job satisfaction of PT. BPR Modern Express Ambon.

The results of the regression analysis of non-financial compensation variables (X2) on job satisfaction of employees of PT. BPR Modern Express Ambon obtained the value of $t$ calculate $=2.962$ while at $\alpha=0.05$ and $\mathrm{df}=42$ obtained the value of $\mathrm{t}$ table $=1.681$ because $\mathrm{t}$ calculate $>\mathrm{t}$ table. This data proves that partially non-financial compensation variables significantly have influence on employee job satisfaction of PT. BPR Modern Express Ambon.

The research results showed that the independent variable of financial compensation is the independent variable that has a dominant influence compared to the other independent variables. This can be known because the financial compensation variable has the highest 
regression coefficient, namely 0,529 compared to other independent variables, in addition, the value of $t$ calculate of the financial compensation variable also has the largest value amounted to 6.767 . Thus, hypothesis II which states that the variable financial compensation has a dominant influence, in this case can be accepted and statistically tested.

\section{DISCUSSION OF RESULTS}

The research findings show that financial and non-financial compensation influences job satisfaction. The findings of this study are supported by research by Rachmandika et al. (2016), Wahyu (2017) Rohman et al (2018) that financial and non-financial compensation has influences on job satisfaction.

This finding is confirmed According to Rivai (2011: 741) financial compensation consists of direct financial compensation and indirect financial compensation. Direct financial compensation consists of wages, salaries, and incentives in accordance with the workload, achievements made by employees and carried out periodically based on timeliness. Indirect financial compensation consists of all payments that do not cover in the direct financial compensation including vacations, various types of insurance, and holiday allowances.

One factor that influences job satisfaction is compensation. Compensation is anything that is received by employees in return for their work in the organization. Compensation is divided into two types, direct and indirect compensation. The purpose of providing compensation, among others, to attract, maintain and motivate employees to excel. An increase in employee job satisfaction is determined by fairness of compensation, level of compensation, and practices related to compensation administration.

Employee job satisfaction has different levels according to job assignments and employee self-conditions. This is job satisfaction according to Martoyo (2007: 156) "The emotional state of employees whether occurs or not occurs a meeting point between the value of employee compensation from the company / organization with the level of compensation value that is desired by the employee concerned". The same thing was said by Handoko (2008: 193) "Job satisfaction is a pleasant or unpleasant emotional state with which employees view their work. Job satisfaction reflects one's feelings towards his work ". Job satisfaction is an evaluation that illustrates someone's feelings of comfort or discomfort, satisfaction and dissatisfaction at work.

Compensation can be used as a way to build employee job satisfaction. In order to improve employee job satisfaction, compensation determination process needs to consider the requirements of fairness and feasibility. Internal justice/ fairness can be done through job evaluation, while external justice is done by wage / salary surveys. The problem of job satisfaction is greatly influenced by financial compensation and non-financial compensation. Financial and non-financial compensation is an important determinant of employee job satisfaction performance. Hypothesis testing results show that financial compensation and non-financial compensation tested has a positive and significant effect on job satisfaction of employees of PT. BPR Modern Express Ambon. This shows that the higher the attention of the leadership on the financial and non-financial compensation, it will affect the increase in employee job satisfaction. In addition, in this study it can be proved that the variables that has a dominant influence on job satisfaction of employees of PT. BPR Modern Express Ambon is financial compensation.

\section{CONCLUSION AND RECOMMENDATIONS}

Financial compensation has a positive and significant effect on employee job satisfaction. This can be seen from the value of $t$ calculate $>t$ table $(6,767>1,681)$ and significance value < significance level (a) 0,05 $(0,000<0,05)$.

Non-financial compensation has a positive and significant effect on employee performance. This can be seen from the value of $t$ calculate $>t$ table $(2,962>1,681)$ and significance value $<$ significance level $(\alpha) 0,05(0,005<0,05)$. 
Financial compensation and non-financial compensation simultaneously had a positive and significant effect on employee performance. This can be seen from the value of $F$ calculate $>$ F table $(54,691>3,22)$ and significance value $<$ significance level $(\alpha) 0,05(0,000$ $<0,05)$.

Suggestion given by researcher to PT. BPR Modern Express Ambon to maintain and increase financial and non-financial compensation, because these two variables can increase job satisfaction. In addition to other researchers, in the future studies should expand the research sample, not only to employees of PT. BPR Modern Express Ambon alone, but can take samples from trading and manufacturing companies, so that the research results can be more generalized.

\section{REFERENCES}

1. Arampatzi, E., Burger, M., lanchovichina, E., Röhricht, T., \& Veenhoven, R. (2018). Unhappy development: Dissatisfaction with Life on the Eve of the Arab Spring. Review of Income and Wealth, 64, S80-S113.

2. Bilson,Simamora,2004, Riset Pemasaran, Jakarta, Gramedia Utama

3. Dwi, G., Syafrizal. (2011). Analisa Pengaruh Kepuasan Kerja Terhadap Turnover Intention Serta Dampaknya Terhadap Kinerja Karyawan. Skripsi S-1 Fakultas Ekonomi. Semarang: Universitas Diponegoro. Tidak Dipublikasikan.

4. Froese, F. J., Peltokorpi, V., Varma, A., \& Hitotsuyanagi-Hansel, A. (2019). Merit-based Rewards, Job Satisfaction and Voluntary Turnover: Moderating Effects of Employee Demographic Characteristics. British Journal of Management, 30(3), 610-623.

5. Handoko, T. Hani. 2008. Manajemen Personalia dan Sumberdaya Manusia. Yogyakarta:BPFE Yogyakarta

6. Honeyman, R., \& Jana, T. (2019). The B Corp Handbook: How You Can Use Business as a Force for Good. Berrett-Koehler Publishers.

7. Jung, Y., \& Suh, Y. (2019). Mining the voice of employees: A text mining approach to identifying and analyzing job satisfaction factors from online employee reviews. Decision Support Systems, 113074.

8. Martoyo, Susilo. 2007. Manajemen Sumber Daya Manusia. Yogyakarta: BPFE Yogyakarta

9. Rachmandika, I., Al Musadieq, M., \& Mayowan, Y. (2016). Pengaruh Kompensasi Finansial Dan Kompensasi Non Finansial Terhadap Kepuasan Kerja Karyawan (Studi Pada Karyawan PT Semen Indonesia (Persero) Tbk). Jurnal Administrasi Bisnis, 33(1), 9-17.

10. Rivai, Veithzal. 2004. MSDM untuk perusahaan: Dari Teori Ke Praktek. Jakarta: PT. Raja Grafindo Persada.

11. Robbins, Stephen P. 2001. Perilaku Organisasi: Konsep, Kontroversi, Aplikasi, Jilid 1, Edisi 8, Prenhallindo, Jakarta

12. Rohman, M. A., Wulan, H. S., \& Haryono, A. T. (2018). Pengaruh kompensasi, lingkungan kerja dan kebijakan pemimpin terhadap prestasi kerja dimediasi kepuasan kerja sebagai variabel intervening di pt. Pelangi kinasih tunggal karsa semarang. Journal of Management, 4(4).

13. Schmitt, M., \& Dörfel, M. (1999). Procedural injustice at work, justice sensitivity, job satisfaction and psychosomatic well-being. European Journal of Social Psychology, 29(4), 443-453.

14. Stamolampros, P., Korfiatis, N., Chalvatzis, K., \& Buhalis, D. (2019). Job satisfaction and employee turnover determinants in high contact services: Insights from Employees' Online reviews. Tourism Management, 75, 130-147.

15. Sultan, K., Ismael, G., Mohammad, O., Abas, S., \& Abdulla, M. (2019). Human Resource Management Practices and Its Effects on Job Satisfaction Levels of Employees. International Journal of Research in Business and Social Science (2147-4478), 8(2), $102-$ 112. 
16. Syaifullah, I. I., Titisari, P., \& Puspitasari, N. (2019). Work Satisfaction In Compensation Mediation and Motivation on Productivity Permanent Employees of Pt. Sinergi Mitra Utama in Bandung. International Journal of Scientific Research and Management, 7(03).

17. Wahyu, E. E. (2017). Pengaruh Kompensasi Finansial Dan Kompensasi Non Finansial Terhadap Kepuasan Kerja Karyawan Pada Sweet Garden Guest House Malang. Jurnal Administrasi dan Bisnis (adbis), 11(2), 167-176.

18. Zainudin, M. I., Rashid, M. S. A., Murugeesan, Y., Zainal, C., \& Malek, S. N. A. (2019). Islamic Working Environment, Organizational Commitment and Employee's Job Satisfaction and Performance in Malaysia Service Industry: A Conceptual Paper. Global Business \& Management Research, 11(1). 